\title{
Payment Method Code
}

National Cancer Institute

\section{Source}

National Cancer Institute. Payment Method Code. NCI Thesaurus. Code C93619.

A coded value specifying the method by which payment is delivered. 